\title{
Influence of an Alternative Soil Management System to Herbicide Use on Tree Vigor, Yield, and Quality of Apple Fruit
}

\author{
Kamila Łucja Bokszczanin *, Dariusz Wrona and Sebastian Przybyłko \\ Department of Pomology and Horticulture Economics, Institute of Horticultural Sciences SGGW, \\ Nowoursynowska 159 Str., 02-787 Warsaw, Poland; dariusz_wrona@sggw.edu.pl (D.W.); \\ sebastian_przybylko@sggw.edu.pl (S.P.) \\ * Correspondence: kamila_bokszczanin@sggw.edu.pl
}

check for updates

Citation: Bokszczanin, K.Ł.; Wrona, D.; Przybyłko, S. Influence of an Alternative Soil Management System to Herbicide Use on Tree Vigor, Yield, and Quality of Apple Fruit. Agronomy 2021, 11, 58. https://doi.org/10.3390 /agronomy11010058

Received: 1 December 2020 Accepted: 25 December 2020 Published: 29 December 2020

Publisher's Note: MDPI stays neutral with regard to jurisdictional clai$\mathrm{ms}$ in published maps and institutional affiliations.

Copyright: (C) 2020 by the authors. Licensee MDPI, Basel, Switzerland. This article is an open access article distributed under the terms and conditions of the Creative Commons Attribution (CC BY) license (https:// creativecommons.org/licenses/by/ $4.0 /)$.

\begin{abstract}
The aim of this study was to investigate the effect of alternative soil maintenance systems in a 'Gold Chief' apple orchard to the herbicide strip on tree growth, yield, and optimal fruit quality during 2012-2016. We compared several floor management systems: organic mulch comprised of Miscanthus spp., mechanical cultivation, black polypropylene cover, and herbicide strip as the control, with particular emphasis on the suitability and effectiveness of the organic mulch. During this five-year experiment Miscanthus spp. mulched trees grew most vigorously and significantly more than trees from other systems. The increment of the trunk cross-sectional area was higher for Miscanthus spp. mulched trees when compared to both mechanical fallow and herbicide strip. On average, fruits from trees grown in Miscanthus spp. plots were significantly larger than fruits from mechanical fallow and black polypropylene cover plots. The cumulative yield from the entire experiment was not significantly different for organic mulch, herbicide strip, and black polypropylene cover and was significantly higher than the mechanical cultivation. Different floor management systems had a significant effect on the solid soluble content in fruit both directly after harvesting and after storage. Our study shows that organic mulch can be a good alternative for soil management in orchard production systems.
\end{abstract}

Keywords: floor management; non-chemical weed control; Miscanthus spp. mulch; herbicide strip; black mechanical fallow; black polypropylene woven ground cover; apple quality

\section{Introduction}

The purpose of soil management in orchards is first and foremost to control plants competing with the trees. The method of soil maintenance has a direct impact on its structure [1], temperature [2], and water relations [3], while the condition of the soil should not hinder agrotechnical operations in the orchard and fruit harvesting. Therefore, when choosing a soil maintenance method, one should be guided by its effectiveness and the level of costs incurred, as well as the impact on the mechanical, physicochemical and microbiological properties of the soil [4]. In practice, in the cultivation of fruit trees, due to their specificity resulting from the perennial nature of plants and the row cultivation system, a mixed system is used. Traditionally growers have used a grass drive row (turf) in the alleyway and an herbicide-treated strip in the tree row for weed control. A common management method is to eradicate weeds, either permanently or temporarily, also through traditional tillage along the tree row [5].

The majority of fruit growers currently use herbicide fallow as a standard soil maintenance system because of its low cost and broad-spectrum weed efficacy. Its effectiveness depends on the active substance of the herbicide, method of application, and weather conditions in which the procedure is performed [6]. The advantage of using herbicides are their reliability, low price, and ease and speed of application [7]. However, the improper use of herbicides can cause damage to crop plants and negatively affect the rhizosphere by disrupting the uptake of macro- and micro-elements; this is also the case with glyphosate, 
which is commonly used in orchards [8,9]. The scientific literature consistently suggests that the effects of herbicide application could significantly alter soil function. These include disruptions to earthworm ecology in soils exposed to glyphosate and atrazine, the inhibition of soil $\mathrm{N}$-cycling (including biological $\mathrm{N}_{2}$-fixation, mineralization, and nitrification) by sulfonylurea herbicides in alkaline or low organic matter soils, and site-specific increases in disease resulting from the application of a variety of herbicides $[10,11]$.

Among the alternatives to the herbicide fallow soil maintenance system in tree rows, mechanical cultivation and mulching of crops with both synthetic materials (black foil agrotextile) and organic matter (manure, sawdust, straw, and wood chips) are the most promising [12]. Mechanical cultivation is the most commonly used system in the first years after tree planting. However, maintaining mechanical cultivation promotes the deterioration of soil structure, may cause an excessive rapid decomposition of organic matter [13], can limit the development of soil fauna [14] and can damage tree roots developing in the surface layer of the soil [15]. In addition, the control of perennial weeds with this method often does not bring the expected results [4]. In turn, the use of black foil or agrotextile to cover the soil in rows of plants completely reduces the negative effect of weeds and maintains a high level of humidity. Still, according to [16] and [17], it adversely affects the other physicochemical properties of the soil, as well as its mineral and humus content. Therefore, this system is not fully beneficial in terms of agrotechnics and ecology [12].

In light of current trends and attempts to limit the negative impact of crop intensification on the natural environment, and in addition to the primary goal of weed control, methods that will measurably inhibit irreversible soil degradation processes are in demand. Hence, increasing notice is being paid to the use of various types of natural mulch, which, in addition to significantly enriching the soil with organic matter and improving its quality, can also play a role in mitigating the effects of excessive greenhouse gas emissions [18-20]. Furthermore, a growing concern for tree nurseries and orchards is that most of the dwarfing apple rootstocks used in modern apple cultivation are susceptible to apple replant disease (ARD), also known as soil decline [21]. This problem has been known for centuries, although the ultimate causes are still not fully recognized. After repeated growth of the same plant species, the soil loses its capacity to support the growth of plants of the respective species. Replant disease results in poor vegetative development, stunted growth, and reduced yield in terms of both quantity and quality [21]. The introduction of a large amount of organic matter into the soil through the mulching of crops has been shown to stimulate the activity of microorganisms and, by increasing their diversity, enriches the microbiological life of the soil [22]. Above all, however, it has a positive effect on the proper development of the root system by stabilizing soil temperature and humidity [23].

Due to the constant tightening of EU policy on the use of plant protection products and the withdrawal of certain active substances (including herbicides) from widespread use, the importance of alternative soil maintenance systems in tree rows is expected to steadily increase. Our hypothesis was that alternative soil maintenance systems to herbicide use could have a good impact on tree vigor, yield, and quality of apple fruit. The results of our study, which was conducted to assess the suitability of non-chemical methods of weed control, provides valuable advice for other practitioners.

\section{Materials and Methods}

The trial was set up in spring 2012 and covered five growing seasons. The study was conducted in the experimental orchard of the Warsaw University of Life Sciences, Wilanów, Poland. The plant material consisted of apple Malus $\times$ domestica Borkh. cultivar 'Gold Chief' grafted on M.9 rootstock. Trees were planted in $3.5 \times 1.4 \mathrm{~m}$ spacing in deep, loamy alluvial soil, with $2.5 \%$ of humus. Trees were trained in a spindle-bush system. The weather conditions during the course of the trial are presented in Figure 1. Data were collected during the experiment using the Davis Vantage Pro 7 field weather station installed in the experimental orchard. 


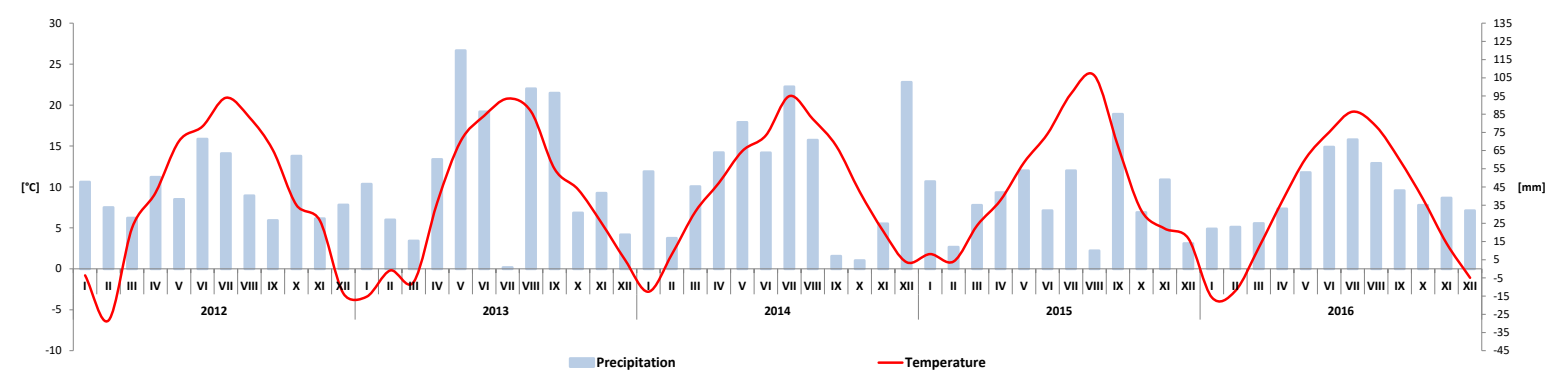

Figure 1. Weather conditions in the 'Gold Chief' apple orchard during 2012-2016.

The experiment was set up using a randomized block design. The following methods of soil management in $1 \mathrm{~m}$ wide rows of trees were compared: (1) Herbicide strip (HS), was used as a control, for which $1 \mathrm{~m}$ soil width was sprayed with herbicide (glyphosate in the Roundup $360 \mathrm{SL}$ formulation at a dose of $4 \mathrm{Lha}^{-1}$ ) at the beginning of June and after fruit harvesting at the beginning of October in each year of the experiment; (2) organic litter (MM), for which $1 \mathrm{~m}$ width of soil was mulched in rows of trees with a $10 \mathrm{~cm}$ layer of shredded straw from Miscanthus spp., and straw was also added during the trial as required to maintain the original litter thickness; (3) mechanical cultivation (MC), which was kept in rows of trees $1 \mathrm{~m}$ wide using a rototiller-type tool mounted on the rear of a tractor equipped with a hydraulic system, enabling access to the area between trees, and the soil was tilled up to $10 \mathrm{~cm}$ deep up to six times during the growing period (from April to October) depending on weather conditions; (4) synthetic mulch (BC), for which a soil strip $1 \mathrm{~m}$ wide was mulched in rows of trees with black polypropylene woven ground cover of $100 \mathrm{~g}$ per $\mathrm{m}^{2}$ density. Each combination was replicated four times on plots, each consisting of eight randomly distributed trees. The same practices of pruning and disease and pest control were applied for all management systems in accordance with the standards of Integrated Pest Management.

\subsection{Tree Growth}

Tree growth was expressed as a trunk cross-sectional area (TCSA) and its increment during the experiment. TCSA was calculated on the basis of trunk diameter measured $30 \mathrm{~cm}$ above the ground. Measurements were made directly after tree planting in May of the first year and were followed in late October at the end of each season covered by the trial. The results are given in $\mathrm{cm}^{2}$.

\subsection{Yield Assessment}

The yield was assessed annually in autumn during the harvest of fruit. The obtained values were measured in $\mathrm{kg} \cdot \mathrm{tree}^{-1}$. For all combinations of the experiment, the cropping efficiency index (CEI) was determined. It was computed as the quotient of yield and trunk cross-sectional area. This value was given in $\mathrm{kg} \cdot \mathrm{cm}^{-2}$.

The biennial bearing index (BBI) was computed using crop yields in the years 2012-2016. BBI was defined according to [24]. The value of BBI averages the absolute differences between yields of two consecutive harvests and varies from zero to one. The higher the value, the more pronounced the alternation, or oscillation, of production; that is, a value of zero indicates constant production while one indicates alternated yielding.

\subsection{Fruit Analysis}

Fruit quality was evaluated for each year of the study, both immediately after harvest (end of September) and after ten weeks of storage in a normal atmosphere (NA). The harvest date was determined by a starch test using a common rating system on a scale of one to ten, with one being completely unripe and ten being fully ripe. The 'Gold Chief' apples were harvested when the starch test index was five to six. All quality characteristics, 
except the mean fruit mass and color, were determined on a sample of ten apples from each plot.

The mean fruit mass was calculated from a sample of 30 fruits for each replicate and was measured on an analytical balance.

Fruit firmness was determined using an Instron 5540-type penetrometer. For this purpose, a narrow strip of skin was peeled from the fruit, both on the side of the blush and on the opposite side, revealing the flesh. Measurements were taken directly in the flesh, with an $11 \mathrm{~mm}$ diameter pin penetrating the flesh to $10 \mathrm{~mm}$ depth. The results were measured in kG.

The solid soluble content (SSC) was determined in the juice pressed from fruits tested for each replication. The SSC was evaluated directly in juice using ATAGO PAL 1 type refractometer and was measured in ${ }^{\circ}$ Brix.

Fruit skin color was estimated on a sample of 30 fruits for each plot and based on the developed skin coloring scale, where apples were divided into three following classes depending on the surface of the fruit covered with blush: $0-25 \%, 26-50 \%, 51-100 \%$. The measurement was performed organoleptically.

\subsection{Statistical Analysis}

The study was a completely randomized design with four replications per each treatment combination. Statistical analysis was conducted using analysis of variance (ANOVA) tests, and mean values separation was made by the Newman-Keuls multiple ranged test at the $p<0.05$ significance level. The analysis was conducted using Statgraphics Plus 4.1 software.

\section{Results}

The TCSA, calculated on the basis of trunk diameter measured directly after tree planting in spring 2011, showed that plants were homogenous in size. It was observed that different floor management systems designed within tree rows differentiated TCSA values. Trees mulched with Miscanthus spp. (MM) showed relatively high TCSA values in all years of the study, but significant differences were noted from 2014. The MM system had significantly higher TCSAs compared to HS in 2014, all other systems in 2015, and HS and BC in 2016. The TCSA results are consistent with the TCSA increments measured from the start to the end of the experiment. Significantly higher values of TCSA were found for trees in the MM system compared to those from both BC and HS systems. The trees in the HS system showed the lowest TCSA increment (Figure 2).

The cumulative yield from 2012-2016 was similar for the HS, MM, and BC systems and was significantly higher compared to the MC system (Table 1 ). The crop efficiency index was significantly higher for both HS and BC than for MC. It corresponded to the highest values, which were observed in $\mathrm{HS}$ and BC plots, while the lowest was noted for MC (Table 1). It was observed that the BC treatment had a negative effect on the uniformity of fruiting between years; thus, it contributes to biennial bearing. The biennial bearing index was significantly lower under MC in comparison to BC (Table 1, Figure 3).

Table 1. Yield, crop efficiency, and biennial bearing index of apple trees cv. Gold Chief during 2012-2016, depending on the soil management system.

\begin{tabular}{|c|c|c|c|c|c|c|c|c|}
\hline \multirow{2}{*}{ Treatment } & \multicolumn{5}{|c|}{$\begin{array}{c}\text { Yield } \\
\left(\mathrm{kg} \cdot \text { Tree }^{-1}\right)\end{array}$} & \multirow{2}{*}{$\begin{array}{c}\text { Cumulative Yield } \\
\text { 2012-2016 } \\
\left(\mathrm{kg} \cdot \text { Tree }^{-1}\right)\end{array}$} & \multirow{2}{*}{$\begin{array}{l}\text { Crop } \\
\text { Efficiency Index } \\
\left(\mathrm{kg} \cdot \mathrm{cm}^{-2}\right)\end{array}$} & \multirow{2}{*}{$\begin{array}{c}\text { Biennial } \\
\text { Bearing Index }\end{array}$} \\
\hline & 2012 & 2013 & 2014 & 2015 & 2016 & & & \\
\hline HS & $4.7 a^{*}$ & $8.3 \mathrm{a}, \mathrm{b}$ & $11.8 \mathrm{a}$ & $21.1 \mathrm{~b}$ & $12.9 \mathrm{a}$ & $58.7 \mathrm{~b}$ & $3.62 \mathrm{~b}$ & $0.24 \mathrm{a}, \mathrm{b}$ \\
\hline $\mathrm{MC}$ & $3.9 \mathrm{a}$ & $6.7 \mathrm{a}$ & $10.2 \mathrm{a}$ & $14.9 \mathrm{a}$ & $10.4 \mathrm{a}$ & $46.1 \mathrm{a}$ & $2.34 \mathrm{a}$ & $0.21 \mathrm{a}$ \\
\hline MM & $3.2 \mathrm{a}$ & $9.2 \mathrm{a}, \mathrm{b}$ & $12.6 \mathrm{a}$ & $20.5 \mathrm{~b}$ & $13.1 \mathrm{a}$ & $58.6 \mathrm{~b}$ & $2.56 \mathrm{a}, \mathrm{b}$ & $0.26 \mathrm{a}, \mathrm{b}$ \\
\hline $\mathrm{BC}$ & $3.8 \mathrm{a}$ & $12.1 \mathrm{~b}$ & $11.0 \mathrm{a}$ & $22.5 \mathrm{~b}$ & $9.48 \mathrm{a}$ & $58.9 \mathrm{~b}$ & $3.33 \mathrm{~b}$ & $0.34 \mathrm{~b}$ \\
\hline
\end{tabular}

* Means followed by the same letter within a column do not differ significantly according to the Newman-Keuls test at $p<0.05$; HS: Herbicide strip; MC: Mechanical cultivation; MM: Miscanthus spp. mulch; BC: Black polypropylene woven ground cover. 


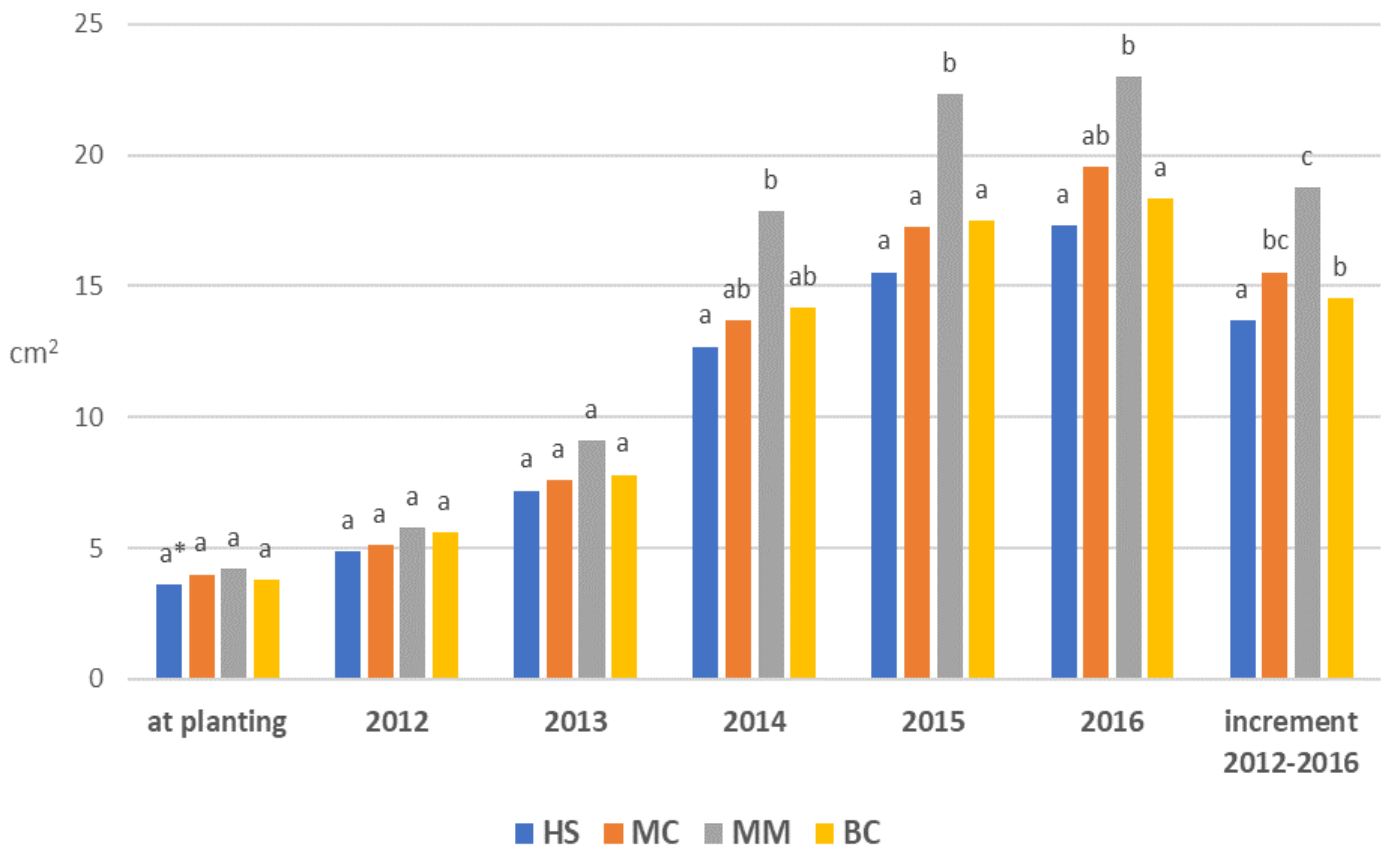

Figure 2. Trunk cross-section area (TCSA) and TCSA increment of apple tree cv. Gold Chief using different soil management systems during 2012-2016. HS: Herbicide strip; MC: Mechanical cultivation; MM: Miscanthus spp. mulch; BC: Black polypropylene woven ground cover. * means followed by the same letter within a year do not differ significantly according to the Newman-Keuls test at $p<0.05$.

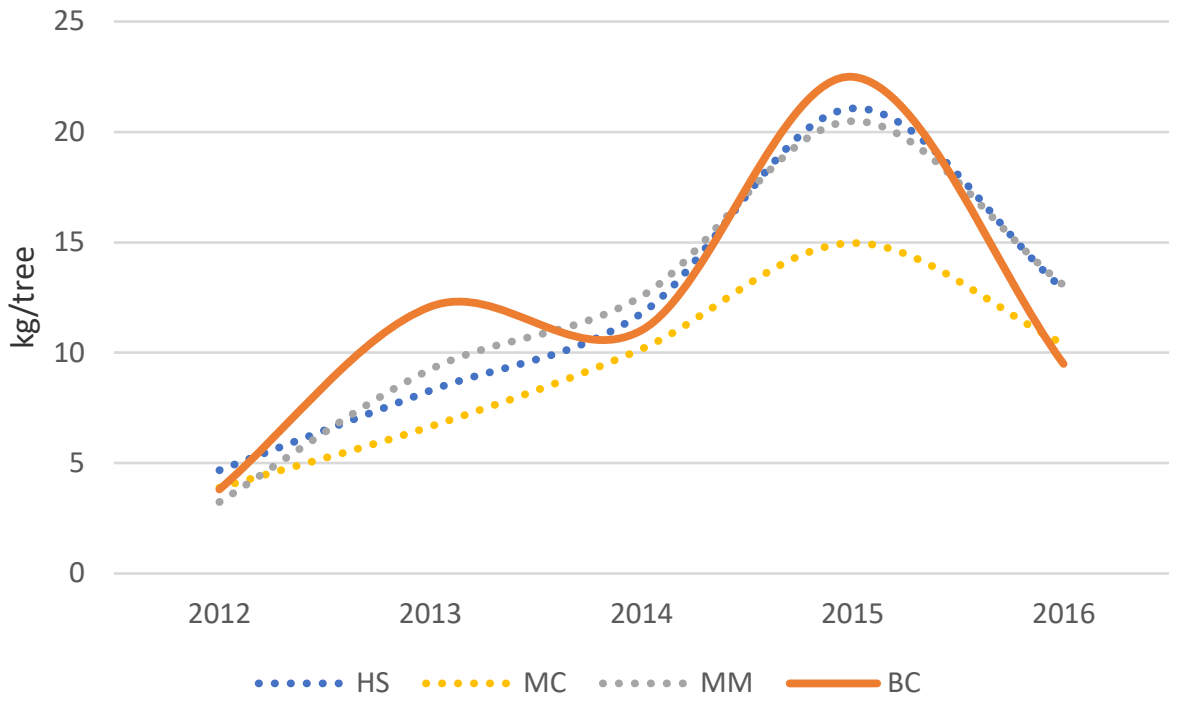

Figure 3. Biennial bearing index of Gold Chief/M.9 with different floor management systems during 2012-2016. HS: Herbicide strip; MC: Mechanical cultivation; MM: Miscanthus spp. mulch; BC: Black polypropylene woven ground cover.

The results concerning the mean fruit mass of trees maintained in soil systems were not uniform between years, but certain regularities were observed. In 2012 and 2015, the fruits from trees grown in MM plots were significantly larger compared to the MC and $\mathrm{BC}$ management systems, respectively. This is reflected in the average results for all years of the experiment, where fruit mass for MM was significantly higher than in other systems (Table 2). 
Table 2. Fruit quality parameters of apple trees cv. Gold Chief depending on the soil management system measured directly after harvest during 2012-2016.

\begin{tabular}{|c|c|c|c|c|c|c|c|}
\hline Parameter & Treatment & 2012 & 2013 & 2014 & 2015 & 2016 & $\begin{array}{c}\text { Mean } \\
2012-2016\end{array}$ \\
\hline \multirow{4}{*}{$\begin{array}{l}\text { Fruit mass } \\
\qquad(\mathrm{g})\end{array}$} & HS & $188 \mathrm{a}^{*}$ & $192 \mathrm{a}$ & $224 \mathrm{a}$ & $198 \mathrm{a}, \mathrm{b}$ & $214 \mathrm{a}$ & $203 \mathrm{a}$ \\
\hline & $\mathrm{MC}$ & $190 \mathrm{a}$ & $184 \mathrm{a}$ & $223 a$ & $205 a, b$ & $216 a$ & $203 a$ \\
\hline & $\mathrm{MM}$ & $213 b$ & $191 \mathrm{a}$ & $241 \mathrm{a}$ & $211 \mathrm{~b}$ & $217 \mathrm{a}$ & $215 b$ \\
\hline & $\mathrm{BC}$ & $204 a, b$ & 183 a & $231 \mathrm{a}$ & 189 a & $210 \mathrm{a}$ & $203 \mathrm{a}$ \\
\hline \multirow{4}{*}{$\begin{array}{c}\text { Firmness } \\
(\mathrm{kg})\end{array}$} & HS & $7.0 \mathrm{a}$ & $7.1 \mathrm{a}$ & $7.8 \mathrm{a}$ & $6.4 \mathrm{a}$ & $6.7 \mathrm{a}$ & $7.1 \mathrm{a}$ \\
\hline & $\mathrm{MC}$ & $7.1 \mathrm{a}$ & $7.1 \mathrm{a}$ & $7.8 \mathrm{a}$ & $6.8 \mathrm{a}$ & $7.1 \mathrm{a}$ & $7.2 \mathrm{a}$ \\
\hline & MM & $7.6 \mathrm{a}$ & $7.1 \mathrm{a}$ & $7.6 \mathrm{a}$ & $6.6 \mathrm{a}$ & $6.9 \mathrm{a}$ & $7.2 \mathrm{a}$ \\
\hline & $\mathrm{BC}$ & $7.5 \mathrm{a}$ & $6.5 \mathrm{a}$ & $7.9 \mathrm{a}$ & $6.4 \mathrm{a}$ & $7.1 \mathrm{a}$ & $7.1 \mathrm{a}$ \\
\hline \multirow{4}{*}{$\operatorname{SSC}\left({ }^{\circ}\right.$ Brix $)$} & HS & $12.7 \mathrm{a}$ & $14.5 \mathrm{a}$ & $15.2 \mathrm{a}$ & $13.3 \mathrm{a}$ & $14.1 \mathrm{a}$ & $14.0 \mathrm{a}$ \\
\hline & $\mathrm{MC}$ & $15.1 \mathrm{~b}$ & $14.8 \mathrm{a}$ & $15.2 \mathrm{a}$ & $13.7 \mathrm{a}$ & $13.8 \mathrm{a}$ & $14.5 \mathrm{~b}$ \\
\hline & $\mathrm{MM}$ & $14.6 \mathrm{~b}$ & $14.6 \mathrm{a}$ & $15.2 \mathrm{a}$ & $13.7 \mathrm{a}$ & $14.0 \mathrm{a}$ & $14.4 \mathrm{a}, \mathrm{b}$ \\
\hline & $\mathrm{BC}$ & $14.8 \mathrm{~b}$ & $14.1 \mathrm{a}$ & $15.2 \mathrm{a}$ & $13.8 \mathrm{a}$ & $14.0 \mathrm{a}$ & $14.4 \mathrm{a}, \mathrm{b}$ \\
\hline
\end{tabular}

* Means followed by the same letter within column do not differ significantly at $p<0.05$. HS: Herbicide strip; MC: Mechanical cultivation; MM: Miscanthus spp. mulch; BC: Black polypropylene woven ground cover; SSC: solid soluble content.

MC positively influenced SSC content in apples directly after harvest, but only in comparison to HS (Table 2). After storage, significantly higher rates of SSC were observed in MC and MM compared with HS (Table 3). There was no significant effect of soil maintenance in the orchard on fruit firmness, neither directly after harvest nor after storage (Tables 2 and 3).

Table 3. Fruit quality parameters of apple tree cv. Gold Chief grown in different soil management systems measured after ten weeks of storage during 2012-2016.

\begin{tabular}{|c|c|c|c|c|c|c|c|}
\hline Parameter & Treatment & 2012 & 2013 & 2014 & 2015 & 2016 & $\begin{array}{c}\text { Mean } \\
\text { 2012-2016 }\end{array}$ \\
\hline \multirow{4}{*}{$\begin{array}{c}\text { Firmness } \\
\text { (kG) }\end{array}$} & HS & $5.1 \mathrm{a}^{*}$ & $5.8 \mathrm{a}$ & $5.8 \mathrm{a}$ & $3.9 \mathrm{a}$ & $4.69 \mathrm{a}$ & $5.08 \mathrm{a}$ \\
\hline & $\mathrm{MC}$ & $5.2 \mathrm{a}$ & $5.8 \mathrm{a}$ & $5.7 \mathrm{a}$ & $4.1 \mathrm{a}$ & $4.78 \mathrm{a}$ & $5.16 \mathrm{a}$ \\
\hline & $\mathrm{MM}$ & $5.3 \mathrm{a}$ & $5.8 \mathrm{a}$ & $5.7 \mathrm{a}$ & $4.0 \mathrm{a}$ & $4.70 \mathrm{a}$ & $5.11 \mathrm{a}$ \\
\hline & $\mathrm{BC}$ & $5.0 \mathrm{a}$ & $5.7 \mathrm{a}$ & $5.8 \mathrm{a}$ & $3.9 \mathrm{a}$ & $4.50 \mathrm{a}$ & $5.01 \mathrm{a}$ \\
\hline \multirow{4}{*}{$\begin{array}{c}\text { SSC } \\
\left({ }^{\circ} \text { Brix }\right)\end{array}$} & HS & $13.5 \mathrm{a}$ & $15.3 \mathrm{a}$ & $15.4 \mathrm{a}$ & $13.3 \mathrm{a}$ & $13.8 \mathrm{a}$ & $14.2 \mathrm{a}$ \\
\hline & $\mathrm{MC}$ & $14.1 \mathrm{a}, \mathrm{b}$ & $15.3 \mathrm{a}$ & $15.5 \mathrm{a}$ & $15.1 \mathrm{~b}$ & $14.7 \mathrm{a}, \mathrm{b}$ & $15.0 \mathrm{~b}$ \\
\hline & $\mathrm{MM}$ & $14.6 \mathrm{a}, \mathrm{b}$ & $15.2 \mathrm{a}$ & $15.3 \mathrm{a}$ & $14.6 \mathrm{a}, \mathrm{b}$ & $15.1 \mathrm{~b}$ & $14.9 \mathrm{~b}$ \\
\hline & $\mathrm{BC}$ & $15.1 \mathrm{~b}$ & $15.1 \mathrm{a}$ & $15.4 \mathrm{a}$ & $14.0 \mathrm{a}, \mathrm{b}$ & $14.4 \mathrm{a}, \mathrm{b}$ & $14.8 \mathrm{a}, \mathrm{b}$ \\
\hline
\end{tabular}

* Means followed by the same letter within column do not differ significantly. HS: Herbicide strip; MC: Mechanical cultivation; MM: Miscanthus spp. mulch; BC: Black polypropylene woven ground cover; SSC: solid soluble content.

The lowest percentage of the least colored fruit was recorded for both HS and MM, and it was $37.2 \%$ and $33.9 \%$, respectively (Figure 4). Moreover, both MM and MC were the combinations with the highest percentage of fruit with a blush covering $>50 \%$ of the skin surface of the fruit (Figure 4). 


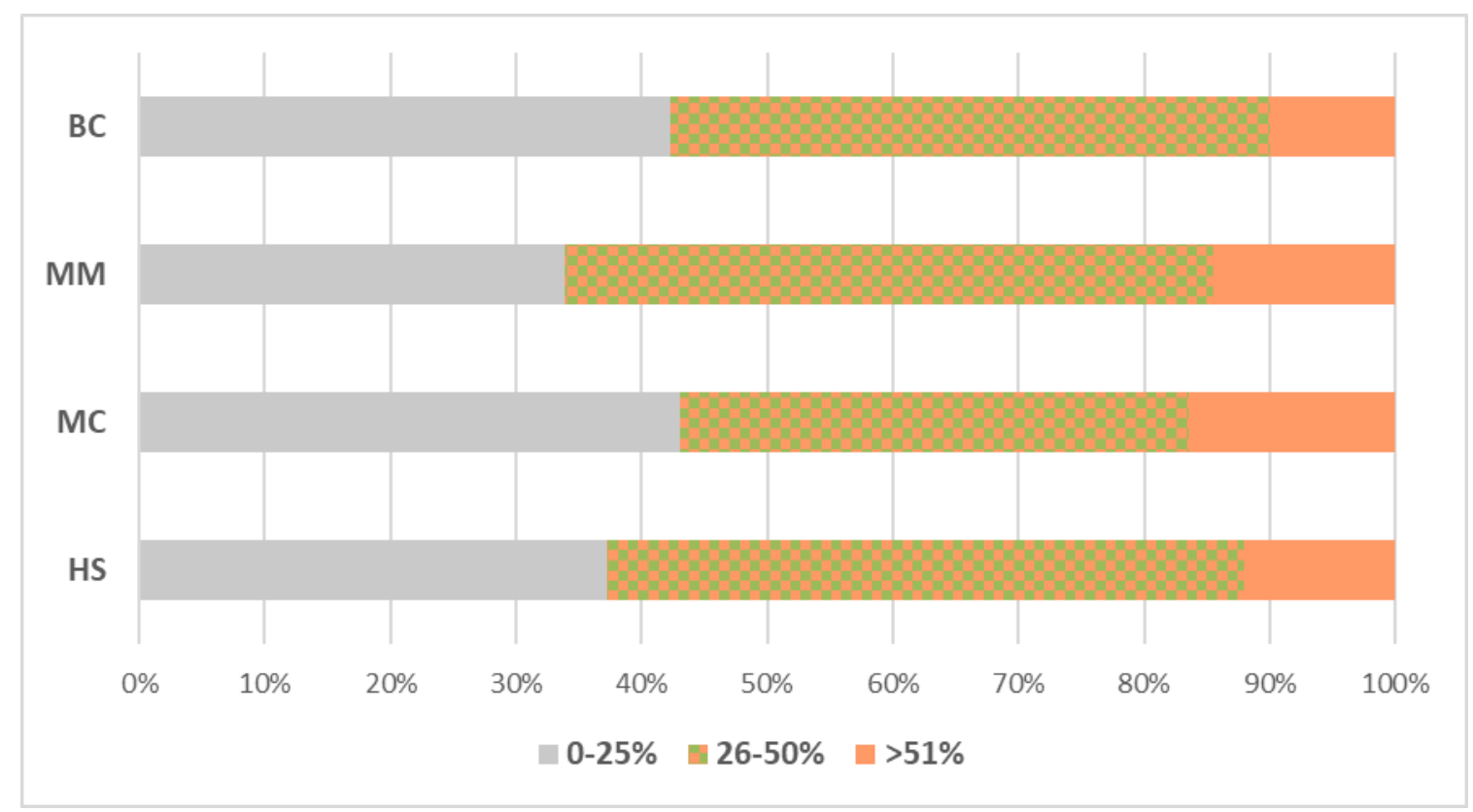

Figure 4. Fruit coloring of apple trees cv. Gold Chief grown under different soil management systems during 2012-2016. HS: Herbicide strip; MC: Mechanical cultivation; MM: Miscanthus spp. mulch; BC: Black polypropylene woven ground cover.

\section{Discussion}

Conventional soil management, involving either herbicide use or rotary tillage for weed control without any vegetation or mulch, has resulted in soil degradation and a decrease in fruit yield and quality [25]. The consequent loss of soil water and lack of soil organic matter is the most important limiting factors in local agriculture that have been observed. As a result, many studies exploring an effective management practice to improve orchard soil conditions and fruit quality have been conducted [26-31]. The results indicate that management involving a surface floor covering can effectively improve the soil moisture as well as soil nutrient availability, leading to better tree performance compared with tillage management.

In our study, the different soil maintenance systems used in the apple orchard resulted in variations of vegetative growth of the trees. Miscanthus spp. mulched trees grew most vigorously and were significantly stronger in comparison with all other systems, $\mathrm{HS}$ or BC, depending on the year. These results were consistent with TCSA increment results, which were higher for Miscanthus spp. mulch when compared to both BC and HS systems. A previous study [32] observed higher trunk cross-sectional area and fruit yield in hay-straw mulch, but also in both post-emergence and pre-emergence herbicides. The impacts of living litter on tree size in this study confirm previous reports of the critical importance of weed suppression in establishing deciduous orchards [33-36]. As [37] observed, the TCSA of trees in the hardwood mulch treatment surpassed that in mowed turfgrass as well as pre-emergence soil-active herbicide treatment during eight of 11 years of growing an apple orchard. It was confirmed that the presence of live litter contributes to a significant increase in the total nitrogen content in the arable layer in relation to other cover plants, as well as mulching with agrotextile [38]. It was shown that apple trees in mulch developed a shallower root system [39].

It is expected that reduced size plants produce lower quantities of fruit, but with higher yield and yield efficiency. Yield efficiency (YE) and cumulative YE indexes, expressed in $\mathrm{kg}$ $\mathrm{cm}^{-2}$ or $\mathrm{g} \mathrm{cm}^{-2}$ of the trunk cross-sectional area, are the most utilized metrics to compare plants of different sizes in trials designed to evaluate rootstocks, planting densities, training systems, and growth regulators [40]. YE enables comparison of annual results, whereas 
cumulative YE evaluates long term effects, such as cumulative yield, over several years, depending on final TCSA.

Correlations between YE and yield per tree and between YE and trunk cross-sectional area (TCSA) confirmed that efficiency could be increased by the production increment or by vigor reduction of the plant [41]. Here, mechanical cultivation negatively influenced the growth of trees. The five-year cumulative yield was similar for trees in herbicide strip, Miscanthus spp. mulch, and black cover treatments, and was significantly higher when compared to MC. The crop efficiency index was significantly higher for apple trees maintained in both herbicide strip and black cover systems in comparison to mechanical cultivation. It may be possible that mechanical tillage increases soil respiration and reduces tree vigor, but it does not have a sufficient effect on weed competition and thus leads to reduced fruit yield. It has been shown that tillage can have negative effects on the growth of young trees [35] and soil quality [42]. It also increases nitrogen leaching from the root zone, impedes internal water drainage [33], disrupts the root surface [16], and lowers soil cation exchange capacity and soil organic matter content [43]. To avoid these negative impacts, mechanical tillage should be replaced with other floor management systems that are productive under the constraints of organic fruit growing [44].

In our five year experiment, the average results of fruit mass depended on the soil maintenance system and were significantly higher in the case of Miscanthus spp. mulch than the other systems. According to [45], spreading Miscanthus spp. chips maintain soil moisture and promote soil fertility, as well as vegetative and reproductive growth of young apple trees. The three organic mulches (sawdust, pine bark, or grass clippings) enhanced vegetative growth when compared with manual weeding, measured as a length of one-year-old shoots, leaf area of leaves taken from bourse shoots ( $27 \%$ versus $12 \%)$, and tree trunk cross-section area ( $23 \%$ versus $13 \%)$. With the mulches, yield and fruit mass were increased by $35 \%$ and $17 \%$ compared with manual weeding, respectively [39]. Over the five years, we observed $5.6 \%$ higher fruit mass in the Miscanthus spp. mulch system than the other soil maintenance systems.

We observed significant differences in the SSC of fruits, which was significantly higher for MC versus HS. After storage, the fruit' SSC noted in MC was significantly higher in comparison to the HS system. A previous study [46] noted that the SSC responded positively to integrated floor management practices that replaced the standard herbicide system. In the experiment of [47], fruits from fallow interrow treatment had the highest content of soluble solids $(13.2 \%)$, while the green manure and fallow combination had the least $(12.9 \%)$. They did not observe significant differences in soluble solids content and fruit flesh firmness. The significant decrease of the mentioned indicators may suggest excessive nitrogen nutrition [48,49].

In our study, the yield of 'Gold Chief' /M.9 depended on the floor management system used. The biennial bearing index was the lowest under MC and significantly lower in comparison to the BC system. It can be assumed that the mechanical fallow, herbicide strip, and Miscanthus spp. mulch maintenance systems ensure a more even fruit yield from year to year.

\section{Conclusions}

A comparison of different soil management strategies in an orchard showed that nonchemical tree row management could be a good alternative to the commonly used herbicide strip. The exception is using mechanical fallowing, which on the one hand, increases the uniformity of the yield in subsequent years and contributes to an increase in the content of soluble solids in the fruit, but on the other, reduces yield. Among the assessed systems, special attention should be paid to organic mulch made of Miscanthus spp., a renewable natural raw material that, unlike herbicide, has no harmful impact on the environment. This could be an effective method of soil maintenance in both integrated and organic production. Our research shows that mulching trees with shredded Miscanthus spp. straw increases the tree's vigor and fruit size, and therefore may have a beneficial effect on physical and/or 
chemical soil parameters. The next step in our research will be to determine the impact of Miscanthus spp. straw use on the soil environment, particularly in terms of organic matter content, availability of major minerals nutrients, and water relations in the long term.

Author Contributions: Conceptualization, K.Ł.B., S.P., and D.W.; Funding acquisition, D.W.; Investigation, S.P.; Methodology, S.P., D.W.; Visualization, K.Ł.B., S.P.; Supervision, D.W.; Writing—original draft, K.Ł.B., S.P.; Writing-review and editing, K.Ł.B., S.P., and D.W. All authors have read and agreed to the published version of the manuscript.

Funding: This research was funded by the Polish Ministry of Science and Higher Education within funds of the Institute of Horticultural Sciences.

Institutional Review Board Statement: Not applicable.

Informed Consent Statement: Not applicable.

Data Availability Statement: Data is contained within the article.

Acknowledgments: Authors would like to thank Jacek Marszał (Department of Pomology, Institute of Horticultural Sciences, Warsaw University of Life Sciences-WULS) for his participation in the experiment.

Conflicts of Interest: The authors declare no conflict of interest.

\section{References}

1. Neumann, G.; Kohls, S.; Landsberg, E.; Stock-Oliveira Souza, K.; Yamada, T.; Röhmeld, V. Relevance of glyphosate transfer to non-target plants via the rhizosphere. J. Plant Dis. Prot. 2006, 20, 963-969.

2. Zobiole, L.H.S.; Oliveira, R.S., Jr.; Huber, D.M.; Constantin, J.; De Castro, C.; Oliveira, F.A.; Oliveira, A., Jr. Glyphosate reduces shoot concentration of mineral nutrients in glyphosate-resistant soybeans. Plant Soil 2010, 328, 57-69. [CrossRef]

3. Hagner, M.; Mikola, J.; Saloniemi, I.; Saikkonen, K.; Helander, M. Effects of a glyphosate-based herbicide on soil animal trophic groups and associated ecosystem functioning in a northern agricultural field. Sci. Rep. 2019, 9, 8540. [CrossRef] [PubMed]

4. Rose, M.T.; Cavagnaro, T.R.; Scanlan, C.A.; Rose, T.J.; Vancov, T.; Kimber, S.; Kennedy, I.R.; Kookana, R.S.; Van Zwieten, L. Impact of Herbicides on Soil Biology and Function. Adv. Agron. 2016, 136, 133-220. [CrossRef]

5. Stockmann, U.; Adams, M.A.; Crawford, J.W.; Field, D.J.; Henakaarchchi, N.; Jenkins, M.; Minasny, B.; McBratney, A.B.; De Courcelles, V.D.R.; Singh, K.; et al. The knowns, known unknowns and unknowns of sequestration of soil organic carbon. Agric. Ecosyst. Environ. 2013, 164, 80-99. [CrossRef]

6. Reim, S.; Siewert, C.; Winkelmann, T.; Wöhner, T.; Hanke, M.-V.; Flachowsky, H. Evaluation of Malus genetic resources for tolerance to apple replant disease (ARD). Sci. Hortic. 2019, 256, 108517. [CrossRef]

7. Sumorok, B.; Sas Paszt, L.; Głuszek, S.; Derkowska, E.; Żurawicz, E. The effect of mycorrhization and mulching of apple trees 'Gold Millennium' and blackcurrant bushes 'Tiben' on the occurrence of arbuscular mycorrhizal fungi. J. Fruit Ornam. Plant Res. 2011, 19, 35-49.

8. Gao, Y.; Li, Y.; Zhang, J.; Liu, W.; Dang, Z.; Cao, W.; Qiang, Q. Effects of mulch, N fertilizer, and plant density on wheat yield, wheat nitrogen uptake, and residual soil nitrate in a dryland area of China. Nutr. Cycl. Agroecosyst. 2009, 85, 109-121. [CrossRef]

9. Lombard, P.B.; Callan, N.W.; Dennis, F.G., Jr.; Looney, N.E.; Martin, G.C.; Renquist, A.; Mielke, E.A. Towards a standardized nomenclature, procedures, values, and units in determining fruit and nut tree yield performance. HortScience 1988, $23,813-817$.

10. Hoagland, L.; Carpenter-Boggs, L.A.; Granatstein, D.; Mazzola, M.; Smith, J.; Peryea, F.; Reganold, J.P. Orchard floor management effects on nitrogen fertility and soil biological activity in a newly established organic apple orchard. Biol. Fertil. Soils 2008, 45, 11-18. [CrossRef]

11. Delate, K.; McKern, A.; Turnbull, R.; Walker, J.S.; Volz, R.; White, A.; Bus, V.; Rogers, D.; Cole, L.; How, N.; et al. Organic Apple Systems: Constraints and Opportunities for Producers in Local and Global Markets: Introduction to the Colloquium. HortScience 2008, 43, 6-11. [CrossRef]

12. Mia, J.; Massetani, F.; Murri, G.; Facchi, J.; Monaci, E.; Amadio, L.; Neri, D. Integrated Weed Management in High Density Fruit Orchards. Agronomy 2020, 10, 1492. [CrossRef]

13. Lanauskas, J.; Kviklys, D.; Kviklienè, N.; Uselis, N.; Viskelis, P.; Rubauskis, E. Effect of soil management on tree nutrition and yield in apple organic orchards. Acta Hortic. 2014, 1058, 175-180. [CrossRef]

14. Robinson, D.; O'Kennedy, N. The effect of overall herbicide systems of soil management on the growth and yield of apple trees 'Golden Delicious'. Sci. Hortic. 1978, 9, 127-136. [CrossRef]

15. Atkinson, D.; White, G.C. The effects of weeds and weed control on temperate fruit orchards and their environment. In Pests, Pathogens and Vegetation: The Role of Weeds and Wild Plants in the Ecology of Crop Pests and Diseases; Thresh, J.M., Ed.; Pittman: London, UK, 1981; pp. 415-428.

16. Hogue, E.J.; Neilsen, G.H. Orchard Floor Vegetation Management. Hortic. Rev. 2011, 9, 377-430. 
17. Welker, W.V.; Glenn, D.M. Growth responses of peach and changes in soil characteristics with sod and conventional planting systems. J. Amer. Soc. Hort. Sci. 1988, 113, 652-656.

18. Wooldridge, J.; Harris, R.E. Effect of organic mulches and plastic sheet on soil temperature. Decid. Fruit Grow. 1991, 41, 118-121.

19. Merwin, I.A.; Stiles, W.C.; van Es, H.M. Orchard groundcover management system impacts on soil physical properties. J. Am. Soc. Hort. Sci. 1994, 119, 216-222. [CrossRef]

20. Merwin, I.A.; Stiles, W.C. Orchard Groundcover Management Impacts on Apple Tree Growth and Yield, and Nutrient Availability and Uptake. J. Am. Soc. Hort. Sci. 1994, 119, 209-215. [CrossRef]

21. Cockroft, B.; Wallbrink, J. Root distribution of orchard trees. Aust. J. Agric. Res. 1996, 17, 49-54. [CrossRef]

22. Lipecki, J.; Berbeć, S. Soil management in perennial crops: Orchards and hop gardens. Soil Till. Res. 1997, 43, 169-184. [CrossRef]

23. Six, J.; Elliott, E.; Paustian, K.; Doran, J.W. Aggregation and Soil Organic Matter Accumulation in Cultivated and Native Grassland Soils. Soil Sci. Soc. Am. J. 1998, 62, 1367-1377. [CrossRef]

24. Fiscus, D.A.; Neher, D.A. Distinguishing sensitivity of free-living soil nematode genera to physical and chemical disturbances. Ecol. Appl. 2002, 12, 565-575. [CrossRef]

25. Russell, E. Soil structure: Its maintenance and improvement. J. Soil Sci. 2006, 22, 137-151. [CrossRef]

26. Świca, M.; Paluszek, J.; Domżał, H. Influence of herbicide fallows on soil structure and aggregate water stability of soil in apple orchard. Acta. Agrophys. 2006, 8, 1005-1016.

27. Beeck, C.; Pude, R.; Blanke, M. Mulching with shredded wood or Miscanthus chips maintains soil moisture and promotes soil fertility as well as vegetative and reproductive growth of young apple trees. Erwerbs-Obstbau 2006, 48, 47-61.

28. Smith, R.E.; Warrick, A.W. Soil water relationships. In Design and Operation of Farm Irrigation Systems, 2nd ed.; Hoffman, G.J., Evans, R.G., Jensen, M.E., Martin, D.L., Elliott, R.L., Eds.; American Society of Agricultural and Biological Engineers: St. Joseph, MI, USA, 2007; pp. 120-159. [CrossRef]

29. Markuszewski, B.; Kopytowski, J. Wpływ kilku sposobów pielegnacji gleby na wzrost i plonowanie jabłoni szczepionych na podkładkach półkarłowych i siewce 'Antonówki' za wstawką B9. Zesz. Nauk. Inst. Sadow. 2008, 16, 21-34.

30. Drozd, J.; Licznar, M.; Licznar, S.E.; Walenczak, K. Losses of organic matter and nitrogen during composting of municipal solid wastes. Pol. J. Soil Sci. 2008, 41, 127-138.

31. Granatstein, D.; Mullinix, K. Mulching Options for Northwest Organic and Conventional Orchards. HortScience 2008, 43, 45-50. [CrossRef]

32. Kühn, B.F.; Pedersen, H.L. Cover Crop and Mulching Effects on Yield and Fruit Quality in Unsprayed Organic Apple Production. Eur. J. Hort. Sci. 2009, 74, 247-253.

33. Ramos, M.E.; Benítez, E.; García, P.A.; Robles, A.B. Cover crops under different managements vs. frequent tillage in almond orchards in semiarid conditions: Effects on soil quality. Appl. Soil Ecol. 2010, 44, 6-14. [CrossRef]

34. Zhang, Y.; Xie, Y.S.; Hao, M.D.; She, X.Y. Effects of different patterns surface mulching on soil properties and fruit trees growth and yield in an apple orchard. J. Appl. Ecol. 2010, 21, 279-286.

35. Atucha, A.; Merwin, I.A.; Brown, M.G. Long-term Effects of Four Groundcover Management Systems in an Apple Orchard. HortScience 2011, 46, 1176-1183. [CrossRef]

36. Licznar-Małańczuk, M. Zastosowanie Żywych Ściółek w Rzędach Drzew Jabłoni Jako Alternatywnego Sposobu Pielęgnacji Gleby w Porównaniu z Ugorem Herbicydowym; Wydawnictwo Uniwersytetu Przyrodniczego we Wrocławiu: Wrocław, Poland, 2012.

37. Solomakhin, A.A.; Trunov, Y.V.; Blanke, M.; Noga, G. Organic mulch in apple tree rows as an alternative to herbicide and to improve fruit quality. Acta Hortic. 2012, 933, 513-521. [CrossRef]

38. Neilsen, G.; Forge, T.; Angers, D.; Neilsen, D.; Hogue, E. Suitable orchard floor management strategies in organic apple orchards that augment soil organic matter and maintain tree performance. Plant Soil 2014, 378, 325-335. [CrossRef]

39. Chen, Y.; Wen, X.; Sun, Y.; Zhang, J.; Wu, W.; Liao, Y. Mulching practices altered soil bacterial community structure and improved orchard productivity and apple quality after five growing seasons. Sci. Hortic. 2014, 172, 248-257. [CrossRef]

40. Wang, G.Y.; Zhang, X.Z.; Wang, Y.; Xu, X.F.; Han, Z.H. Key minerals influencing apple quality in Chinese orchard identified by nutritional diagnosis of leaf and soil analysis. J. Integr. Agric. 2015, 14, 864-874. [CrossRef]

41. Nan, W.G.; Yue, S.C.; Huang, H.Z.; Li, S.Q.; Shen, Y.F. Effects of plastic film mulching on soil greenhouse gases (CO2, CH4 and $\mathrm{N} 2 \mathrm{O}$ ) concentration within soil profiles in maize fields on the Loess Plateau, China. J. Integr. Agric. 2016, 15, 451-464. [CrossRef]

42. Fioravanço, J.C.; Czermainski, A.B.C.; Oliveira, P.R.D. Yield efficiency for nine apple cultivars grafted on two rootstocks. Ciência Rural 2016, 46, 1701-1706. [CrossRef]

43. Nawaz, A.; Lal, R.; Shrestha, R.K.; Farooq, M. Mulching Affects Soil Properties and Greenhouse Gas Emissions under Long-Term No-Till and Plough-Till Systems in Alfisol of Central Ohio. Land Degrad. Develop. 2017, 28, 673-681. [CrossRef]

44. Fioravanço, J.C.; Czermainski, A.B.C. Biennial bearing in apple cultivars. Rev. Ceres 2018, 65, 144-149. [CrossRef]

45. Zheng, W.; Gong, Q.; Zhao, Z.; Liu, J.; Zhai, B.; Wang, Z.; Li, Z. Changes in the soil bacterial community structure and enzyme activities after intercrop mulch with cover crop for eight years in an orchard. Eur. J. Soil Biol. 2018, 86, 34-41. [CrossRef]

46. Ghimire, R.; Bista, P.; Machado, S. Long-term Management Effects and Temperature Sensitivity of Soil Organic Carbon in Grassland and Agricultural Soils. Sci. Rep. 2019, 9, 12151. [CrossRef] [PubMed]

47. Ngosong, C.; Okolle, J.N.; Tening, A.S. Mulching: A Sustainable Option to Improve Soil Health. In Soil Fertility Management for Sustainable Development; Panpatte, D., Jhala, Y., Eds.; Springer: Singapore, 2019. [CrossRef] 
48. Mia, M.J.; Massetani, F.; Murri, G.; Neri, D. Sustainable alternatives to chemicals for weed control in the orchard-A Review. Hort. Sci. 2020, 47, 1-12. [CrossRef]

49. Yang, M.; Wang, S.; Zhao, X.; Gao, X.; Liu, S. Soil properties of apple orchards on China's Loess Plateau. Sci. Total Environ. 2020, 723, 138041. [CrossRef] [PubMed] 